\title{
Francuskie reakcje wobec problemu zjednoczenia Niemiec po II wojnie światowej
}

Sprawa zjednoczenia Niemiec była obecna w polityce Francji po II wojnie światowej i budziła obawy. Celem artykułu jest zbadanie, w jaki sposób Francuzi odpowiadali na niemieckie dążenia i ambicje, by przezwyciężyć podział towarzyszący zimnej wojnie i będący konsekwencją II wojny światowej. Poprzez analizę dokumentów, wspomnień i wypowiedzi polityków zamierzam przywołać wydarzenia, z których wynika, że kwestia zjednoczenia Niemiec po II wojnie światowej nie była obca ani mężom stanu, ani dyplomatom, ani publicystom, ani w końcu przeciętnym obywatelom interesującym się biegiem wydarzeń w ojczyźnie Johanna Wolfganga Goethego. Artykuł napisałam także w oparciu o prace na temat relacji francusko-niemieckich, które ukazywały się w języku polskim, niemieckim, rzadziej odwoływałam się do źródeł w języku francuskim.

Ponieważ o możności działania na arenie międzynarodowej decydowała i decydować będzie potęga, osłabiona w wyniku II wojny światowej Francja wolała, by pokonane Niemcy pozostały rozbite. Pogląd taki nie był przecież obcy francuskiej myśli politycznej. Zarówno Armand-Jean du Plessis Richelieu jak i Georges Clemenceau, czy w końcu głoszący, że „zjednoczenie Niemiec jest sprawą straszliwą” Anatol France nie marzyli o zjednoczonej, silnej Germanii (Koszel, 1996, s. 163; Pastusiak, 1972, s. 128; Schabert, 2002; Trocini, 2012; Gallert, 2012; Tomala, 1990, s. 49-59; Hatys, 1990, s. 71-83; Allemagne: 25 ans après la Réunification; Reunifiaction-Francfort déroule le tapis; La crise des réfugiés; L'Allemagne fête les 25 ans).

Janusz Stefanowicz, podkreślał, że historię Francji odzwierciedlał ,wieloletni sen o potędze", a zjednoczone Niemcy pozbawiłyby swego sąsiada nawet możliwości marzenia o realizacji tejże wizji. Dlatego kryterium francuskiej racji stanu, w której mieściło się utrzymanie przynajmniej równowagi sił w stosunkach z Niemcami musiało ulec zatarciu, gdy perspektywa zjednoczenia Niemiec stawała się coraz bardziej rzeczywista (Stefanowicz, 1996, s. 207). Działo się tak na skutek rozpadu systemu państw socjalistycznych oraz ukierunkowanej na zjednoczenie Niemiec i integrację europejską polityki Niemiec Zachodnich (Stadtmüller, 2002, s. 148).

Relacje francusko-niemieckie zawsze cechowały się znaczną dynamiką. O związkach między państwami pisał między innymi podczas I wojny światowej Jacques Rivière. W dziele Niemcy wysnuł wniosek, że ,jego portret Niemców jest też autoportretem Francuzów”. Tym samym ugruntował tezę Carlo Schmidta o „splątaniu francusko-niemieckim" (Asholt, Kolboom, 1992, s. 179). Ta nie zawsze szczę́liwa więź wynikała z pamięci o toczonych między państwami wojnach. Właśnie przeszłością odzwierciedloną w cezurach 1871, 1914-1918, 1939-1945 warunkowana była chęcią społeczeństwa francuskiego, by zapobiec niebezpieczeństwu zza Renu. Dlatego 
Francuzi określając wizję losu pokonanych Niemiec naciskali, aby pokonanego sąsiada pozostawić $\mathrm{w}$ jak najsłabszej kondycji. W Paryżu próbowano najpierw zapobiec zjednoczeniu Niemiec. Gdy okazało się, że proces ten nastąpi w przyszłości, zaczęto czynić starania, by uchronić we Francji widmo „la grosse Allemagne”. Dlatego Willy Brandt komentował po latach podczas rozmowy z Françoisem Mitterrandem: „wiem [...] niemieckie zjednoczenie obchodzi bardziej Francuzów - nie nas" (Weisenfeld, 1986, s. 9).

Elity polityczne Francji określając strategię postępowania wobec pokonanych Niemiec starały się początkowo wzmocnić swoją pozycją przez wykorzystanie słabości tradycji centralistycznych na północ od Renu. W 1945 roku wyłącznie Francja spośród grona czterech zwycięskich mocarstw opowiadała się za pozbawieniem rozdrobnionych Niemiec centralnego rządu (Stolarczyk, 1995, s. 58). Zdaniem Jerzego Krasuskiego, jednak propagowana przez Francję wizja federalnych, a przez to słabych Niemiec, była anachroniczna. Podkreślał on, że na skutek migracji wywołanych wojną oraz masowego przesiedlenia Niemców ze Wschodu, nastąpiło większe ujednolicenie Niemiec (Krasuski, 1996, s. 30).

Podczas pierwszej fazy kształtowania relacji francusko-niemieckich, od 1944 do 1955 roku Francuzi wielokrotnie reagowali na problem zjednoczenia Niemiec, o czym świadczy sierpniowy memoriał Tymczasowego Rządu Republiki Francuskiej z 1944 roku na temat problemu niemieckiego. Ponadto Charles de Gaulle'a i minister spraw zagranicznych Georges'a Bidault prowadzili rozmowy ze zwycięską trójką na temat pokonanych Niemiec, a generał de Gaulle wygłosił 5 lutego 1945 roku przemówienie radiowe w tej sprawie. Podczas trwania rokowań poczdamskich w sierpniu 1945 roku szczególnie wyraźnie zaznaczyły się podejmowane przez Francję próby przeciagnięcia na swoją stronę ZSRR, by znacznie i skutecznie osłabić Niemców (Parzymies, 1990, s. 69; Mikołajczyk, 2007, s. 52).

Historia podzielonego Berlina także jest częścią drogi Niemców do zjednoczenia. O sytuacji miasta decydowały ustalenia aliantów, które miały już miejsce począwszy od 1943 roku, gdy powołano Europejską Komisję Doradczą. W skład jej gremium od 27 listopada 1944 roku dołączył przedstawiciel Francji - René Massigli. Szczegółowo o sytuacji Berlina zdecydowano w protokołach z 12 września i 14 listopada 1944 roku (Riklin, 1964, s. 19-35). Podzielony najpierw na trzy (Francuzi jako ostatni otrzymali sektor w Berlinie z wyodrębnionego terytorium przez Brytyjczyków i Amerykanów - otrzymali zarząd nad dzielnicami Reinickendorf i Wedding) (Zwei Staaten), a następnie cztery sektory, podporządkowany był Berlin władzy Wielkiej Czwórki. W 1949 roku nastąpiło włączenie sektora radzieckiego do NRD, a mocarstwa zachodnie władały w składającym się z ich sektorów Berlinie Zachodnim. Ani USA, ani Wielka Brytania, ani Francja nie chciały zrezygnować ze swoich praw (Czubiński, 1991b, s. 11-12). Wybuch dwóch kryzysów dowodził skali napięć między mocarstwami i o tym, jak zapalnym punktem na kuli ziemskiej w dwubiegunowym świecie był Berlin.

Dyplomaci francuscy opowiadali się przeciwko centralizacji Niemiec jeszcze podczas konferencji ministrów spraw zagranicznych Ernesta Bevina (Wielka Brytania), Georges'a Bidaulta (Francja), Wiaczesława Michaiłowicza Mołotowa (ZSRR) i generała George'a Marshalla (USA) w Moskwie 22 marca 1947 roku. Opcja ta i próby 
współpracy z Józefem Stalinem musiały zostać zarzucone. Przeorientowanie francuskiej racji stanu spowodowane było przede wszystkim kryzysem ekonomicznym, który panował w państwie. W Quai d' Orsay zrozumiano, że sanacja gospodarki może się powieść wyłącznie przy pozyskaniu wsparcia finansowego ze strony USA. Służył temu plan generała George’a Marshalla, który stał się jednym z ogniw integracji zachodnioeuropejskiej. W wyniku obrad nad sprawą niemiecką podczas konferencji londyńskiej, która trwała od 25 listopada do 15 grudnia 1947 roku Francuzi zgodzili się, że naród niemiecki powinien otrzymać w przyszłości możliwość „przywrócenia jedności państwowej" (Parzymies, 1994, s. 47).

8 kwietnia 1949 roku w Waszyngtonie zdecydowano o połączeniu stref okupacyjnych Francji, Wielkiej Brytanii i Stanów Zjednoczonych, czyli utworzeniu Trizonii. Następnie Francuzi przystali na utworzenie ze stref okupowanych przez Wielką Trójkę Republiki Federalnej Niemiec. Rząd francuski musiał ulec presji zachodnich aliantów, aby uporać się z problemami gospodarczo-społecznymi. Jednocześnie politycy próbowali wygrywać interesy Francji w obliczu pogłębiającego się na świecie konfliktu ideologiczno-polityczno-ekonomiczno-militarnego między Wschodem i Zachodem.

Gdy w 1949 roku okazało się, że istnienie dwóch państw niemieckich, prozachodniej RFN i satelickiej wobec ZSRR NRD, jest procesem nieuchronnym i obiektywnym, we Francji dążono do realizacji w stosunkach z Niemcami schumanowskiego tryptyku: „bezpieczeństwo, równość, pojednanie”, czyli próbowano nałożyć Niemcom ,gorset” (Wickert, 1990, s. 21) przez uruchomienie jak największej liczby mechanizmów współpracy między państwami. Wynikało to z chęci zapobieżenia konfliktom i obawy przed przewagą ekonomiczną Niemiec.

9 maja 1950 roku, w piątą rocznicę kapitulacji Niemiec, przedstawiono projekt, by współpraca francusko-niemiecka w zakresie gospodarowania węglem i stalą odbywała się pod wspólnym nadzorem, a 18 kwietnia 1951 roku został zawarty układ między Belgia, Francją, Holandią, Luksemburgiem, RFN i Włochami w sprawie utworzenia Europejskiej Wspólnoty Węgla i Stali. Zadaniem rządu francuskiego była ochrona nie tylko interesów gospodarczych, ale również bezpieczeństwa swojego państwa. Francja opowiadała się za zakazem dostępu i produkcji przez Niemcy broni atomowej. 24 października 1950 roku premier Francji René Pleven wystąił z inicjatywą utworzenia armii europejskiej, ponieważ Francuzom zależało, by Niemcy nie miały silnej armii (Łukaszewski, 1998, s. 63; Romaniuk-Całkowska, 2004, s. 48-49).

Ważnym impulsem w sprawie zjednoczenia Niemiec było porozumienie bońskie. 26 maja 1952 roku sekretarz stanu USA Dean Acheson, minister spraw zagranicznych Wielkiej Brytanii Anthony Eden, minister spraw zagranicznych Francji Robert Schuman oraz kanclerz Konrad Adenauer podpisali w Bonn układ o stosunkach między RFN a trzema mocarstwami, który znosił status okupacyjny. Dyplomaci wyrazili oczekiwanie, że zjednoczone Niemcy będą demokratycznym i zintegrowanym ze Wspólnotą Europejską państwem. Porozumienie bońskie dotyczyło prerogatyw mocarstw zwycięskich odnośnie Niemiec i Berlina. W konwencji poruszono kwestie ,zjednoczenia Niemiec i pokojowego uregulowania kwestii niemieckiej, jak też stacjonowania sił zbrojnych na terytorium RFN $i$ ich powiększenia bez zgody rządu tego kraju w przypadku ataku z zewnątrz lub groźby takiego ataku" (Vertrag; Parzymies, 1994, s. 48). 
Chociaż państwa EWWiS podpisały 27 maja traktat o Europejskiej Wspólnocie Obronnej, to sprawa remilitaryzacji Niemiec Zachodnich wzbudzała dyskusje wśród francuskich polityków i Zgromadzenie Narodowe zagłosowało 30 sierpnia 1954 roku przeciwko układowi (Łastawski, 2006, s. 110-113).

23 października 1954 roku w Paryżu zostały zawarte układy między Wielką Brytanią, Francja, Belgia, Holandia, Luksemburgiem, Stanami Zjednoczonymi Ameryki, Kanada, Włochami i RFN. Strony umowy zdecydowały o zniesieniu statusu okupacyjnego i postanowily, że:

\section{Artykuł 2.}

Z uwagi na sytuację międzynarodową, która uniemożliwiła dotychczasowe zjednoczenie Niemiec i zawarcie traktatu pokojowego, trzy mocarstwa zachowują dotychczas przez nie wykonywane lub posiadane prawa i odpowiedzialność w stosunku do Berlina i do Niemiec jako całości, włącznie ze zjednoczeniem Niemiec oraz zawarciem traktatu pokojowego.

\section{Artykuł 4}

Aż do wejścia w życie układów w sprawie niemieckiego wkładu obronnego trzy mocarstwa zachowują nadal swoje dotychczas wykonywane lub posiadane prawa odnośnie do stacjonowania sił zbrojnych w Republice Federalnej. Zadaniem tych sił będzie obrona wolnego świata, do którego należą Republika Federalna i Berlin.

\section{Artykuł 7}

Aż do zawarcia traktatu pokojowego państwa-sygnatariusze będą współdziałać w urzeczywistnianiu środkami pokojowymi ich wspólnego celu: zjednoczenia Niemiec mających ustrój wolnościowo-demokratyczny podobny do tego, jaki ma Republika Federalna i zintegrowanych ze Wspólnotą Europejską (Vertrag; Krasuski, 1996, s. 34-38).

RFN znalazła się 9 maja 1955 roku w strukturach NATO, co wymogło na Francji również potrzebę wypowiedzenia się w sprawie jedności Niemiec. Szczególne piętno na kształcie francuskiej polityki wobec Niemiec odcisnął Charles de Gaulle, który wykreował koncepcję „odprężenia, porozumienia i współpracy (,détente, entente, cooperation”). Swoje poczynania oparł na refleksji skierowanej do André Frossarda: „Europa to Niemcy i my. Reszta to płotki" (Łukaszewski, 1998, s. 72). Zamiarem de Gaulle'a było rozwiązanie niemieckiego problemu poprzez zakotwiczenie RFN w Europie. Odpowiadało to tezie opartej na założeniu, że Francja będzie dopiero wielka, gdy będzie musiała zmierzyć się z wielkimi zadaniami, wynikającymi z gaullistowskiej filozofii państwa. Podział Niemiec sprzyjał podtrzymaniu przez Francję statusu mocarstwowego, a postulaty de Gaulle’a nie straciły na aktualności właściwie aż do zjednoczenia Niemiec. Wyrażały się one najpierw w poglądzie, że podział Niemiec na dwa państwa gwarantował bezpieczeństwo Francji i jej dążenie do przewodniej roli na kontynencie. Generał de Gaulle opowiadał się za nienaruszalnością powojennych granic, zakazem dostępu Niemiec do broni nuklearnej, integracją zjednoczonych Niemiec w ramach Wspólnoty Europejskiej, w końcu potrzebą wyrażenia przez sąsiadów Niemiec zgody na zjednoczenie (Stolarczyk, 1995, s. 155-156). Na jednej z konferencji prasowych de Gaulle stwierdził: ,zjednoczenie obu części w jedne Niemcy, które byłyby całkowicie wolne, wydaje się nam być normalnym przeznaczeniem narodu niemieckiego 
pod warunkiem, że to zjednoczenie nie zakwestionuje obecnych granic na zachodzie, wschodzie, północy i południu oraz pod warunkiem, że zjednoczone Niemcy zamierzają zintegrować się w określoną traktatami organizację całej Europy dla współpracy, wolności i pokoju" (Pastusiak, 1972, s. 154; Schabert, 2002, s. 155-156).

W V Republice Francuskiej generał de Gaulle i Michel Debré opowiadali się za budowaniem dobrych relacji z Niemcami, pod warunkiem, że nie zakłócą one pokoju w Europie. Ambicją Francuzów było dorównanie Niemcom Zachodnim pod względem gospodarczym i finansowym. Generał de Gaulle wymagał, by Niemcy uznali granicę na Odrze i Nysie Łużyckiej. Francuski polityk przypominał, że zjednoczenie Niemiec wymaga zgody ,zainteresowanych narodów” i ponownie sprzeciwił się sytuacji, w której Niemcy posiadałyby broń atomową. Ponadto de Gaulle przypomniał, że Niemcy zachodnie przywiązują dużą wagę do relacji z USA, podczas gdy Francuzom zależy na silnej, niezależnej Europie (Schabert, 2002, s. 158-161).

Francuski mąż stanu de Gaulle i kanclerz RFN Adenauer doprowadzili do podpisania 22 stycznia 1963 roku traktatu francusko-niemieckiego, który poprzez współpracę na trzech płaszczyznach: polityki zagranicznej, obronnej i kulturowej, miał przyczynić się do rozwoju kooperacji między tymi państwami. Kolejny raz został potwierdzony cel de Gaulle'a - owocna współpraca w ramach Wspólnot i umocowanie RFN w europejskich instytucjach. Od podpisania traktatu elizejskiego Francuzi i Niemcy deklarowali chęć współpracy i potrzebę działań na rzecz pojednania między narodami (Traité de l'Elysée; Guérin-Sendelbach, 1997, s. 156; Schabert, 2002, s. 40; Dominik, 2001, s. 123; Romaniuk-Całkowska, 2004, s. 92-96).

Aby wzmocnić pozycję przetargową Francji i tym samym osłabić RFN wykorzystywano istnienie Niemieckiej Republiki Demokratycznej. Działo się tak, mimo że 3 października 1954 roku Francja zobowiązała się traktować RFN jako jedynego przedstawiciela narodu niemieckiego (Parzymies, 1994, s. 51). Oficjalne uznanie NRD przez Francję nastąpiło dopiero 9 lutego 1973 roku (Parzymies, 1990, s. 77). Polityka francuska opierała się na popieraniu zjednoczenia Niemiec jako zobowiązania traktatowego. Francuzi deklarowali, że będą aprobować zjednoczenie Niemiec przede wszystkim dlatego, że sam proces zjednoczenia wydawał się być niemożliwy. Sceptyczne stanowisko reprezentowali również sprawujący prezydenturę w latach 1969-1974 Georges Pompidou i jego następca Valery Giscard d'Estaing (1974-1981) (Parzymies, 1994, s. 52).

Zjednoczenie Niemiec nie nastąpiłoby bez zmiany stosunków międzynarodowych rozumianej jako ,przezwyciężenie Jałty”. Proces ten wydawał się politykom francuskim dalece odległy. Dlatego François Mitterrand kontynuował politykę generała Ch. de Gaulle'a, G. Pompidou i V. Giscard d' Estaing’a. Nie wierzył on początkowo w zjednoczenie Niemiec i uważał, że Europa nie uniesie ciężaru wielkich Niemiec jako samodzielnej niekontrolowanej siły (Mazur, 1990b, s. 93). Wypowiadał się mało o podziale Niemiec, a wyjątek stanowią uwagi, które zawarł w Refleksjach nad polityka zagraniczna Francji (Bender, 1995, s. 71). Priorytetem w stosunkach z Niemcami było dla Francji osiagnnięcie stanu, gdzie „Bonn byłoby Bonn”. Był też zdania, że „w tej Europie relacje z Francją są istotne” (Schabert, 2002, s. 93). 21 stycznia 1983 roku w Paryżu przedstawiciele władz Francji i Niemiec Zachodnich - F. Mitterrand, H. Kohl, H.-D. Genscher, Franz-Josef Strauß, Pierre Mauroy, Alain Poher, Lois Mer- 
maz - świętowali dwudziestolecie traktatu elizejskiego. Francuzom zależało tym samym, by Republika Bońska wcielała w życie takie wartości, jak demokracja i pokój. Służyć temu miało podporzą̧kowanie zjednoczenia Niemiec integracji europejskiej oraz umocowanie RFN w NATO, a tym samym uchronienie jej od neutralizmu. Wraz ze stopniowym przekształcaniem się ładu międzynarodowego Mitterrand stwierdzał, że należy równoważyć przeobrażenia, ale w sposób cierpliwy i wyważony (Stolarczyk, 1995, s. 109; Szeptycki, 2005, s. 120-121).

Nie tylko Francja, ale również ZSRR i Wielka Brytania miały interes w utrzymaniu status quo w Niemczech. Dla Europy „,dwupaństwowość była warunkiem równowagi sił i pokoju" (Mazur, 1990a, s. 79). Upadek realnego socjalizmu był procesem nieuchronnym. Michał Gorbaczow był zwolennikiem doktryny Sinatry, która zakładała, że państwa Układu Warszawskiego otrzymają więcej swobody w kreowaniu polityki. Nazwa doktryny przypominała słynną piosenkę Franka Sinatry My Way. Tym samym podział Niemiec okazywał się przestarzały. Wydarzenia w Niemczech Wschodnich nabierały dynamiki. W sierpniu 1989 roku rozpoczęły się masowe ucieczki Niemców, a we wrześniu powstało „Nowe Forum” z udziałem Bärbel Bohley i Jensa Reicha. 18 października 1989 roku nastąpiła dymisja przewodniczącego Rady Państwa NRD Ericha Honeckera.

Gdy 9 listopada 1989 roku padał mur berliński, wojska francuskie stacjonujące w Berlinie, podobnie jak jednostki pozostałych mocarstw okupacyjnych, nie podjęy żadnych działań (Janicki, 1991, s. 272). O ostatecznym uregulowaniu sprawy Berlina postanowiono w układzie z 12 września 1990 roku. Z 1 artykułu tej umowy wynikało, że w skład zjednoczonych Niemiec wejdzie cały Berlin. W artykule 5 przewidziano, że do czasu pobytu radzieckich sił zbrojnych na terenie Berlina pozostawać tam też będą wojska francuskie. Natomiast artykuł 7 dotyczył utraty praw i odpowiedzialności czterech mocarstw na terenie Berlina. Nastapiło rozwiązanie Komendantury Sojuszniczej w Berlinie Zachodnim, który przestał być odrębną jednostką polityczną (Dokument nr 13).

Na toczące się wydarzenia największy wpływ miały USA i ZSRR, ale reakcja Francji również była ważna, m.in. ze względu na obowiązywanie traktatu elizejskiego. Wielu frapowała kwestia przyszłości stosunków francusko-niemieckich, opisywanych choćby jako „tandem”, „oś francusko-niemiecka”, „wspólnota porozumienia”, para, „Entente elementaire”, czy „motor integracji” (Guérin-Sendelbach, 1993, s. 1). F. Mitterrand stwierdził, że nastał czas określenia warunków zjednoczenia Niemiec. W jego mniemaniu powinien przebiec w legitymowany, demokratyczny i pokojowy sposób, w porozumieniu między Związkiem Radzieckim, USA, Wielką Brytanią i Francją. 30 listopada 1989 roku minister obrony Jean-Pierre Chevènement twierdził, że mocarstwa nie są przychylne zjednoczeniu Niemiec (Kiwerska, 1996, s. 104).

Strategia polityki francuskiej wobec problemu zjednoczenia Niemiec opierała się na odwlekaniu biegu wydarzeń. Mimo że F. Mitterrand uznawał prawo Niemców do samostanowienia, domagał się ,jedności niemieckiej w ramach zachodu" (Andrzejewski, 1990, s. 61). Taktyka ta powodowana była obawą przed zmianą układu sił, czyli zachwianiem istniejącej dotychczas koncepcji opartej na równowadze, według formuły André Fontaines'a i Alaina Minc'a, niemieckiej marki i francuskiej bomby (Maull, Meimeth, Neßhöver, 1997, s. 11). Dlatego 10 listopada 1989 roku Roland 
Dumas zaznaczył w wywiadzie udzielonym stacji telewizyjnej RTL, że nie ma postaw do obaw przed zjednoczeniem Niemiec, o ile proces ten będzie przebiegać w sposób pokojowy (Genscher, 1995, s. 663).

Wkrótce elity polityczne Francji musiały ustosunkować się do wygłoszonego 28 listopada przed Bundestagiem planu kanclerza Kohla. Przewidywał on trzy etapy dochodzenia do jedności Niemiec: utworzenie wspólnoty traktatowej, następnie konfederacji, a w końcu „państwowego porządku związkowego w Niemczech”. Francuzi uważali, że Niemcy powinni przestrzegać zapisów o ,umacnianiu współpracy” zawartych w traktacie elizejskim i informować ich o ważnych działaniach na arenie międzynarodowej. Wprawdzie kanclerz nie omówił również planu na wewnętrznej scenie politycznej RFN, ale Francuzi czuli się zawiedzeni. Jedynym powodem zadowolenia, do którego nawiązał Mitterrand, był fakt, że w planie Kohl nie określił ram czasowych dochodzenia do jedności (Andrzejewski, 1990, s. 63; Dokument nr 3).

12 grudnia 1989 roku Roland Dumas opowiedział się przed Zgromadzeniem Narodowym za prawem narodu niemieckiego do samostanowienia. Horst Teltschick ustosunkowując się do stanowiska R. Dumasa zaznaczył, że było ono zgodne z wytycznymi Rady Europy (Teltschick, 1992, s. 66). We Francji podejmowano nadal próby odwlekania zjednoczenia i w tym celu zabiegano o współpracę z Moskwą. W grudniu 1989 roku prezydent Francji F. Mitterrand złożył wizytę w Kijowie. Podczas spotkania z Gorbaczowem poruszył problem realizacji koncepcji wspólnego domu europejskiego, konieczności utrzymania europejskich priorytetów, suwerenności NRD, utrzymania równowagi europejskiej i ewolucyjnych zmian (Czubiński, 1991a, s. 257; Szeptycki, 2005, s. 125). Franz Olivier Giesbert, redaktor naczelny „Nouvel Obserwateur”, a następnie „Le Figaro”, stwierdził, że wizyta Mitterranda w Kijowie była zbędna i mogła zostać odebrana jako szukanie pomocy w ZSRR w blokowaniu zjednoczenia (Giesbert, 1997, s. 497). Z rozprawy Valérie Guérin-Sendelbach wynika natomiast, że sam Mitterrand, podobnie jak de Gaulle, przeceniał rolę ZSRR. Uważał on wszak aż do końca lutego 1990 roku, że Gorbaczow nie wyrazi zgody na jednoczenie Niemiec (Guérin-Sendelbach, 1997, s. 149). Aby potwierdzić rozpowszechnienie podobnych poglądów warto przytoczyć komentarz Mikołaja Purgałowa: ,ze zrozumiałych względów Londyn i Paryż nie odważyły się hamować procesu zjednoczenia narodu niemieckiego, po cichu jednak żywiły nadzieję, że my w Moskwie weźmiemy na siebie tę niewdzięczną, trudną robotę. Kiedy stało się inaczej, ich zaskoczenie było znaczne" (Stolarczyk, 1995, s. 149). We Francji nie zdawano sobie sprawy ze słów, które kierował do Mitterranda Gorbaczow: „Pomóżcie mi przeszkodzić zjednoczeniu Niemiec, w przeciwnym razie zastąpi mnie wojsko. Jeżeli nie uczynicie tego, poniesiecie odpowiedzialność za wojnę" (Wolff-Powęska, 2000, s. 7).

Przedsięwzięciem Mitterranda, które również spotkało się z krytyka, stała się jego podróż do NRD. Jego wizyta wzbudziła przede wszystkim niezadowolenie w Bonn. Doradca kanclerza Kohla, Horst Teltschick skrytykował spotkanie F. Mitterranda z Hansem Modrowem. W „Zapiskach” o zjednoczeniu posłużył się retoryczną figura, gdy nawiązywał do pobytu francuskiego prezydenta w Dreźnie i pytał: „Komu ma (ono) służyć?" (Teltschick, 1992, s. 81). Ze wspomnień samego kanclerza wynika, że wizyta Mitterranda nadszarpnęła przyjaźń między mężami stanu. Pojawiły się głosy o kryzysie stosunków francusko-niemieckich (Kohl, 1999, s. 136). Mitterrand pod- 
czas spotkania ze studentami, intelektualistami i artystami na Uniwersytecie w Lipsku stwierdził, że jedność Niemiec dotyczy najpierw Niemców, a ponieważ dotąd istnieją dwa państwa niemieckie należące do innych systemów, należy uwzględnić sytuację polityczną w Europie. Zdaniem Mitterranda należało uwzględniać europejską równowagę, która opierała się na istnieniu dwóch bloków militarnych i międzynarodowych porozumień. Dlatego podpisał on 21 grudnia 1989 roku z NRD umowę gospodarczą (Begegnung mit Studenten).

Optyka działań Mitterranda uległa zmianie w lutym 1990 roku, kiedy twórca koncepcji „przebudowy i nowego myślenia” przystał na zjednoczenie Niemiec, a RFN zaproponowała NRD niemiecko-niemiecką unię walutową. 13 lutego na konferencji „otwartego nieba" KBWE w Ottawie ministrowie spraw zagranicznych RFN, NRD, Francji, Wielkiej Brytanii, USA i ZSRR zdecydowali, że zostaną przeprowadzone negocjacje $2+4$, podczas których nastapi określenie zewnętrznych aspektów zjednoczenia Niemiec. Takie ograniczenie planowanych negocjacji do kwestii międzynarodowych traktuje się jako uznanie przez mocarstwa okupacyjne prawa narodu niemieckiego do samostanowienia (Czapliński, Janicki, 1991, s. 139; Genscher, 1995, s. 725).

Wobec zwycięskich dla CDU, Niemieckiej Unii Społecznej i Demokratycznego Przełomu wyników wyborów do Izby Ludowej, które miały miejsce w marcu 1990 roku rządowi francuskiemu nie pozostało nic innego, jak akceptacja zjednoczenia i poprawa obustronnych stosunków, aby pogłębić partnerstwo z Niemcami w Europie. To właśnie zakotwiczenie zjednoczonych Niemiec we Wspólnotach zdawało się być remedium na obawy Francji. W stolicy Kanady Hans-Dietrich Genscher powoływał się na myśl Tomasza Manna - , chcemy europejskich Niemiec, a nie niemieckiej Europy”. To między innymi Francja przyzwyczajająca się do wizji pojawienia się jeszcze potężniejszego sąsiada była adresatką tej wypowiedzi (Parzymies, 1994, s. 73).

Wkrótce widoczne się stało, że zjednoczenie Niemiec wymagało uregulowania czterech płaszczyzn stosunków francusko-niemieckich, które znalazły się w porządku dziennym rokowań $2+4$. Były to: kwestie polityczno-militarne uwzględniające zaangażowanie struktur bezpieczeństwa w Europie, problem granic, Berlina, uregulowania dotyczące prawa międzynarodowego oraz ustania praw i odpowiedzialności czterech mocarstw (Hacke, 2003, s. 369).

Wobec aktu inkorporacji NRD do RFN wynikła potrzeba uregulowania kwestii granicy wschodniej. Jej kształt określony został w umowie poczdamskiej z 1945 roku. Zarówno Francja, jak i Polska uważały, że granicy nie można zmieniać po zjednoczeniu Niemiec. Polacy z napięciem przyjmowali istnienie tezy o dalszym formalnym bycie Rzeszy Niemieckiej z 31 grudnia 1937 roku oraz traktowanie jako modus vivendi układu między RFN i Polską z 7 grudnia 1970 roku, który poruszał kwestię granicy. Francja zdecydowanie popierała stanowisko Polski, by uregulować sprawę granic jeszcze przed zjednoczeniem Niemiec. Minister spraw zagranicznych Francji Roland Dumas, opowiedział się za nienaruszalnością granic w Zgromadzeniu Narodowym już 12 grudnia 1989 roku. To właśnie we Francji, 18 stycznia 1990 roku, Kohl oświadczył, że w Niemczech nie wiąże się sprawy zjednoczenia ze zmianą polskiej granicy zachodniej (Teltschick, 1992, s. 94). Sprawę granic Dumas podjął również 1 marca w Berlinie, gdzie stwierdził: ,gołe oświadczenia, choćby najbardziej uroczyste, nie wystarczą. Tego rodzaju istotne sprawy wymagają traktatowych uregulowań 
podlegających ratyfikacji” (Tomala, 1990, s. 107). Również nad Sekwaną dyplomacja francuska i polska oceniały ogłoszoną 8 marca 1990 roku rezolucję Bundestagu o uznaniu nienaruszalności i ostatecznym uregulowaniu granic przez polsko-niemiecki traktat. We Francji gościli wtedy prezydent Wojciech Jaruzelski i premier Tadeusz Mazowiecki. 9 marca Mitterrand stwierdził: „Francja uznaje granicę na Odrze i Nysie za nienaruszalną" (Parzymies, 1990, s. 82-83). W „Le Monde” opublikowano artykuł, w którym stwierdzono, że jeśli Kohl chce być kanclerzem zjednoczenia, to powinien wreszcie, w sposób radykalny usunąć wątpliwości w kwestii granic (Kiwerska, 1996, s. 128). Francuzi podkreślali, że chodzi im o gwarancję nietykalności, a dotąd poruszano kwestię nienaruszalności. Mitterrand rozmawiając z Kohlem wyrażał życzenie, by rokowania z Polską rozpocząć jeszcze przed zjednoczeniem Niemiec. Francja protestowała przeciwko niewymienianiu z nazwy granicy na Odrze i na Nysie, a także popierała uczestnictwo Polski w rokowaniach $2+417$ lipca w Paryżu. Dumas twierdził, że uczestniczenie Polski w rokowaniach jest niezbędne, aby Polacy nie czuli się zaskoczeni (Parzymies, 1994, s. 92). Zabiegi Francji, by uregulować kwestie graniczne, wywołały mogącą pobudzić do dyskusji refleksję H. Teltschicka, że „Francja zawsze stoi po stronie Polski, gdy są problemy z Niemcami” (Teltschick, 1992, s. 141). 21 czerwca 1990 ogłoszono kolejną rezolucję Bundestagu w sprawie granic. Stwierdzono w niej, że zjednoczone Niemcy podpiszą z Polską układ wiążący z punktu widzenia prawa międzynarodowego, w którym granica będzie definitywnie zagwarantowana. Ostatecznie sprawę granic uregulowano 12 września 1990 roku w artykule pierwszym traktatu moskiewskiego. Natomiast polsko-niemiecki traktat graniczny został podpisany 14 listopada 1990 roku.

Obok prac nad uregulowaniem kwestii granicy zjednoczonych Niemiec trwały dyskusje dotyczące architektury bezpieczeństwa w Europie. Głos Mitterranda, by rozwiązać NATO i Układ Warszawski wzbudzał polemikę w środowisku dyplomatów amerykańskich, którzy uważali, że Europa bez wsparcia USA nie zagwarantuje sobie bezpieczeństwa po potencjalnym rozwiązaniu NATO (Rice, Zelikow, 1997, s. 289). 1 marca 1990 Roland Dumas opowiedział się za tym, aby Niemcy odrzuciły neutralność, w której widział niebezpieczeństwo (Parzymies, 1994, s. 69). Jego opinię w kwestii bezpieczeństwa Francji w związku z jednoczeniem Niemiec opublikowano w „The Independent”. Francuz thumaczył: „bezpieczeństwo Francji jest rozgrywane poza jej granicami. Nasz kraj zawsze był zainteresowany solidnymi sojuszami i sojusznikami. Neutralne Niemcy byłyby sercem niestabilnej Europy" (Watson, 1998, s. 299). Do przyczyn wykluczających demilitaryzację należały: obawa przed dryfowaniem Niemiec w stronę Wschodu oraz lęk, że w oparciu o potęgę ekonomiczną Niemcy stałyby się potęgą polityczną i wojskową, a tym samym zagrożeniem dla sąsiadów. Argumentem przeciw neutralizacji była też świadomość faktu, że Francja traktuje RFN jako swoje zbrojne przedpole na wypadek zagrożenia ze Wschodu. We Francji pojawiła się obawa przed „strategiczną pustką” w Europie Środkowej. W czerwcu 1990 roku minister obrony Jean-Pierre Chevénement obawiał się, że w środku Europy powstanie strategiczna pustka zarówno konwencjonalna, jak i nuklearna, co spowoduje, że ZSRR stanie się nuklearną potęgą. Zdaniem ministra wycofanie się USA z Europy i spirala rozbrojeniowa w Europie Zachodniej byłyby niekorzystne. Minister wyraził obawę, że Niemcy mogłyby ograniczyć liczbę swoich wojsk i przypomniał, że kanclerz Kohl 
opowiadał się w Londynie za podwójną opcją zerową (ani artyleria nuklearna, ani rakiety) (Yost, 1990, s. 693). Sam kanclerz Kohl relacjonując rozmowy z Mitterrandem zimą 1989/1990 stwierdził natomiast, że prezydent obawiał się ,zjednoczonych i neutralnych Niemiec powiązanych z Moskwą, bo to oznaczałoby przesunięcie strefy wpływów Związku Radzieckiego aż do rogatek Strasburga” (Kohl, 1990, s. 139; Schabert, 2002, s. 459). Podczas spotkania 4 stycznia 1990 roku Mitterranda z Kohlem w Latché w Gaskonii, które dotyczyło spraw wojskowych ostrzegano przed ,pokusa” (,Versuchung”) neutralizacji Niemiec („Görtemaker”). W interesie Francji leżała budowa autonomicznego wobec Stanów Zjednoczonych systemu obronnego Europy Zachodniej oraz bilateralna współpraca z Niemcami w sferze obrony i bezpieczeństwa. 25 i 26 kwietnia 1990 roku w Paryżu podczas francusko-niemieckich konsultacji potwierdzono, że zjednoczone Niemcy mają należeć do struktur NATO. 17-18 września 1990 roku na szczycie w Monachium Mitterrand zapowiedział częściowe wycofanie żołnierzy francuskich z Niemiec w trakcie nadchodzących dwóch lat (Kohl, 2007, s. 224-225; Genscher, 1995, s. 762).

3 listopada 1989 r. Mitterrand powtórzył w Bonn, że nie boi się zjednoczenia, ale pod warunkiem, że dokona się ono po zjednoczeniu Europy. O tym, że potrzebna jest „silniejsza Europa dwunastki EWG” informował również Hubert Vedrine, rzecznik i doradca prezydenta w sprawach polityki zagranicznej (Teltschick, 1992, s. 24). 18 listopada 1989 r. podczas szczytu Kohl-Mitterrand debatowano nad potrzebą kontynuacji jednoczenia Europy, i przyspieszeniem wprowadzenia unii gospodarczej i walutowej. 30 listopada w Pałacu Elizejskim odbyła się rozmowa H.-D. Genschera z F. Mitterrandem, podczas której przedstawiciel Niemiec opowiedział się za kontynuowaniem kursu integracji. Tym samym nastąpiło ponowne połączenie niemieckiego zjednoczenia z integracją europejską (Genscher, 1995, s. 690). Należy przypomnieć, że Mitterrand już w październiku 1989 roku w Strasburgu na forum Parlamentu Europejskiego opowiadał się za przyspieszeniem i wzmocnieniem integracji Europy (Bender, 1995, s. 73). 8 i 9 grudnia podczas szczytu Wspólnoty Europejskiej w Strasburgu postanowiono o włączeniu do deklaracji końcowej dokumentu w sprawie jedności Niemiec z 12 sierpnia 1970 roku między ZSRR i RFN (układ normalizacyjny), czyli poparto prawo Niemców do samostanowienia. Postanowienia dotyczące Niemiec były opracowywane pod kierunkiem przewodniczącego Komisji Europejskiej, Francuza Jacquesa Delorsa (Kohl, 1999, s. 118-119). W sprawie zjednoczenia Niemiec wypowiedział się senat francuski postulując, żeby Niemcy dążąc do zjednoczenia udowadniały, że popierają proces integracji europejskiej (Teltschick, 1992, s. 43). Prezydent Mitterrand opowiedział się w grudniu 1989 r. za utworzeniem konfederacji europejskiej. Jego koncepcja miała na celu zaprowadzenie stabilizacji w Europie (Koszel, 2004, s. 37). Realizacji tego projektu miały służyć podejmowane zarówno przez Mitterranda, jak i Delorsa inicjatywy. Prezydent, opierając się na wcześniejszych planach zjednoczenia Europy dążył do utworzenia opartej na KBWE konfederacji poprzez pogłębienie więzów z Europą Środkową po wcześniejszym, głębszym powiązaniu ze sobą krajów Europy Zachodniej (Stolarczyk, 1995, s. 171-173). Refleksje dotyczące połączenia integracji europejskiej ze zjednoczeniem Niemiec odzwierciedlone były też w apelu Dumasa z 1 marca 1990 roku, aby utworzyć jednolity rynek. 28 kwietnia na szczycie EWG w Dublinie, Mitterrand i Kohl, optowali za unią walutową i gospodarczą 
państw EWG. Znaczącymi dla sprawy zjednoczenia Niemiec i integracji europejskiej były francusko-niemieckie konsultacje z 25 i 26 kwietnia 1990 roku oraz szczyt EWG w Dublinie z 28 kwietnia. Rozmowy prowadzone podczas obu wydarzeń gwarantowały, że zjednoczenie Niemiec przyspieszy tempo integracji europejskiej, a Niemcy pozostaną wierne myśli Konrada Adenauera: „zawsze z Francją nigdy przeciw USA i jeśli to tylko możliwe w ramach Wspólnoty Europejskiej" (Wiaderny-Bidzińska, 2000, s. 29). Właśnie w Dublinie J. Delors przedstawił plan działania Wspólnoty Europejskiej wobec zjednoczenia Niemiec. Z przedłożonego projektu wynikało, że 1 lipca 1990 roku zostanie wprowadzona unia walutowa. To właśnie w stolicy Irlandii Kohl i Mitterrand optowali nie tylko za przyspieszeniem wprowadzenia wspólnej unii gospodarczej i walutowej, ale też, by 1 stycznia 1993 roku wszedł w życie traktat o unii politycznej. Inicjatywy dublińskie dla Helmuta Kohla były ważnym impulsem w kierunku integracji europejskiej.

12 września 1990 w sali moskiewskiego hotelu Oktiabrskaja H.-D. Genscher (RFN), Lothar de Maiziere (NRD), Douglas Hurd (USA), Edward Szewardnadze (ZSRR), Roland Dumas (Francja) i James Baker (Wielka Brytania) zakończyli negocjacje, które odbywały się 5 maja w Bonn, 22 czerwca w Berlinie i 17 lipca w Paryżu. Na zakończenie procesu $2+4$ został podpisany 12 września 1990 roku w Moskwie układ o osiągnięciu przez Niemcy pełnej suwerenności w sprawach zewnętrznych i wewnętrznych. Na mocy artykułu 7 ustały prawa i odpowiedzialność czterech mocarstw w stosunku do Niemiec i Berlina jako całości. 1 października podczas sesji Zgromadzenia Ogólnego Organizacji Narodów Zjednoczonych USA, ZSRR, Francja i Wielka Brytania zrzekły się odpowiedzialności wobec Niemiec (Hailbronner, 1994, s. 103; Cziomer, 1997, s. 309).

Sam proces zjednoczenia Niemiec był wyjątkowy. Dlatego już u podstaw prób definiowania minionych wydarzeń wystąpiły rozdźwięki. V. Guérin-Sendelbach zaznaczyła obecność różnicy między „Wiedervereinigung” i „Vereinigung”. Pierwszy z terminów, zdaniem francuskiej badaczki kojarzy się z relacjami francusko-niemieckimi w XIX wieku, natomiast określenie „Vereinigung” jest szczególne, bo wskazuje na posiadanie demokratycznej legitymizacji jednoczenia się obu państw niemieckich (Guérin-Sendelbach, 1997, s. 147). Prezydent Mitterrand, gdy próbował definiować sytuację nad Renem, mówił o „Einigung” i podkreślał, że ma na myśli „zjednoczenie dwóch państw niemieckich" (Bender, 1995, s. 78). Joseph Rovan opisał połączenie RFN i NRD w obliczu załamania jałtańskiego porządku, posługując się metaforą: „zdobyto bastylię, tak wielką, jak całe państwo, bez zabicia ani jednego strażnika” (Kaiser, 1991, s. 30).

Kierownik Francuskiego Instytutu Polityki Zagranicznej Dominique Moisi zwrócił uwagę, że nad Sekwaną elity przyjęły upadek muru z zimną kalkulacją i szybko zaczęły szukać sposobu możliwie najbardziej korzystnego zabezpieczenia rangi Francji w Europie (Moisi, 1991, s. 309; Watson, 1998, s. 299). Obawiano się przecież, że zjednoczenie Niemiec osłabi pozycję Francji w trzech wymiarach: nastąpi zniesienie systemu sił czterech mocarstw, Francja nie będzie już symbolicznym suwerenem Niemiec, a ogólne dążenie do powszechnego rozbrojenia i liberalizacja na Wschodzie przeniosą punkt ciężkości starego kontynentu na Wschód. J. Rovan, Henri Menudiér, Pierre Hassner, Alfred Grosser twierdzili, że w przyszłości będzie miała miejsce 
ekspansja Niemiec w Europie Środkowo-Wschodniej i Południowej (Koszel, 1996, s. 171). Dominique Moisi podkreślał, że należy zastąpić koncepcję przypisywaną François'owi Mauriacowi: „kocham Niemcy tak bardzo, że chcę, aby były dwa państwa niemieckie” (Husson, 2008, s. 24) ${ }^{1}$ poglądem: „Potrzebujemy Europy tak bardzo, że chcę zgodzić się na zjednoczone Niemcy" (Burger, 1994, s. 66). Max Gallo, były doradca prasowy Mitterranda w La gouche est morte, vice la guche ostrzegał przed przewagą zjednoczonych Niemiec. M. Gallo obawiał się, że Niemcy mogą spróbować się rozstać ze Wspólnotą Europejska, chcieć czuć się jak równouprawniony partner USA lub Japonii (Bender, 1995, s. 86). Pojawiały się obawy, jaka będzie polityka Niemiec, którą wcześniej de Gaulle sytuował w roli konia ciągnącego zaprzęg powożony przez woźnicę, czyli Francję na trasie jednoczenia Europy (Barzini, 2001, s. 163-164). Franz Joseph Strauss żaląc się na ekspansję Francuzów miał powiedzieć do włoskiego ambasadora w Berlinie, Mario Luccioli: „Niech pan spojrzy na Francję. Czego im nie wolno? Wszystko im uchodzi. Mogliby wręcz powiesić paru kardynałów nie narażając na szwank swoich stosunków ze Stolicą Apostolską" (Barzini, 2001, s. 114; Kolboom, 1991, s. 212-243). Z prasy wynikało, że Francuzi obawiali się, że wraz ze zjednoczeniem osłabną działania Niemców na rzecz integracji. Pojawiły się hasła „Anschluss”, „Niemiecka marka ponad wszystko”. W „Der Spiegel” i w „Le Figaro” można było przeczytać, że z uścisku z Verdun, który wymienili Mitterrand i Kohl pozostała „lodowa uprzejmość”. Pojawiały się też bardziej drastyczne formy obrazowania strachu przed Niemcami - między innymi ukazywane w mediach „karykatury Niemców z pikielhaubą na głowie lub w nazistowskich mundurach" (Kiwerska, 2004, s. 304). Programy telewizyjne we Francji pogłębiały negatywne stereotypy na temat Niemców, ograniczano się do odtwarzania filmów przedstawiających w złym świetle historię Prus, podczas gdy w danym czasie antenowym powinny pojawiać się współczesne sprawozdania społeczno-polityczne (Grosser, 1990, s. 145-146). W mediach francuskich obok oznak niepokoju pojawiły się również wyważone opinie. J. Rovan w „Le Monde” twierdził, że nastapi „godzina obu jedności”, gdyż zjednoczą się nie tylko Niemcy, ale także Europa (Asholt, Kolboom, 1992, s. 181).

Należy zaznaczyć, że opinia publiczna przyjęła z zadowoleniem zjednoczenie Niemiec. Za zjednoczeniem opowiedziało się przecież w lutym 1990 roku 78\% Włochów, 73\% Hiszpanów, 68\% Węgrów, 61\% Brytyjczyków i 51\% Rosjan (Watson, 1998, s. 296). $82 \%$ Francuzów określiło upadek muru berlińskiego jako najważniejsze wydarzenia 1989 roku (Moisi, 1991, s. 210). Ankiety Instytutu SOFRES z lutego 1990 roku wskazywały, że Francuzi zaskoczeni pytaniem: „Czy życzyliby Państwo sobie zjednoczenia Niemiec czy utrzymania dwóch państw niemieckich?” 58\% respondentów opowiadało się za zjednoczeniem, a za pozostawieniem dwóch państw 28\%. Ustosunkowując się do pytania: „Czy myślą Państwo, że zjednoczenie Niemiec ułatwiłoby integrować Europę dwunastki lub że Niemcy tak jak w przeszłości będą próbować zapanować nad Europa??, udzielający odpowiedzi stwierdzali: integrować - 58\%; panować - 30\%. Wobec problemu: „Czy zjednoczenie Niemiec osłabi pozycję Francji w Europie?” pojawiły się

${ }^{1}$ Dokładnie myśl F. Mauriac'a brzmiała: „Nie twierdzę bynajmniej, że stan, w którym są Niemcy, podzielone na dwie części, nie stanowi niebezpieczeństwa dla reszty świata. Co do mnie, bez wątpienia wolę taką sytuację. W dniu, kiedy oba kawałki, nawet porozbijane na atomy, znowu się połączą, będziemy mieli powód do strachu", cytat za: E. Husson, Inne Niemcy, Warszawa 2008, s. 24. 
odpowiedzi: tak - 37\%; wzmocni - 19\%; ani ani - 31\% (Wickert, 1990, s. 149). Warto zaznaczyć, że obawy panujące w społeczeństwie przed Niemcami ustapiły miejsca innym lękom, np. przed fundamentalistami islamskimi. W opinii Zbigniewa Mazura dominował strach przed niemieckim potencjałem gospodarczym wśród elit, a nie obawy przed niemieckim militaryzmem i rewanżyzmem wśród młodzieży (Mazur, 1990b, s. 93). Lęk dotyczył głównie zmian w sferze gospodarczej.

Wydarzenia 1989/1990 przesądziły o ukształtowaniu się ,nowej pozycji wyjściowej Francji" oraz potrzebie oparcia się w stosunkach francusko-niemieckich na zbieżnościach, czyli integracji europejskiej, wspólnej obronie i dzieleniu obciążeń w drodze realizacji wspólnych projektów zbrojnych (Maull, Meimeth, Neßhöver, 1997, s. 69-74). Bez postępującej integracji europejskiej ranga Francji zostałaby dotkliwie ograniczona po zjednoczeniu Niemiec. Francuzom przyszło kooperować z republiką berlińską, a nie bońską, która rozwiała obawy przed „przebudzeniem Niemiec”. Natomiast znaczenie Paryża osłabło, mimo że właśnie Francuzi, a nie Niemcy mogą się poszczycić posiadaniem miejsca w Radzie Bezpieczeństwa oraz statusem, zresztą mniejszej wagi wobec ustania konfliktu Wschód-Zachód, mocarstwa nuklearnego.

\section{Bibliografia}

Allemagne: 25 ans après la Réunification, le défi de l'accueil des réfugiés, http://www.leparisien.fr/international/allemagne-25-ans-apres-la-reunification-le-defi-de-1-accueildes-refugies-03-10-2015-5151727.php\#xtref=https\%3A\%2F\%2Fwww.google.pl\%2F, 2.10.2015.

Andrzejewski I. (1990), Francja a jedność niemiecka, „Zeszyty Niemcoznawcze PISM”, nr V (4).

Asholt W., Kolboom I. (1992), Frankreich und das vereinte Deutschland. Ein Rückblick nach vorn, „Europa - Archiv”, nr 7.

Attali J. (1995), Verbatim. Chronique des annés 1998-1991, Paris.

Barzini L. (2001), Europejczycy, Warszawa.

Begegnung mit Studenten, Intellektuellen und Künstlern an der Karl-Marx Universität in Leipzig am 21. Dezember 1989 (Auszüge). Erklärungen des französischen Staatspräsidentn François Mitterrand zur Deutschen Frage (1990), „Blätter für deutsche und internationale Politik”, $\mathrm{nr} 2$.

Bender K.-H. (1995), Mitterrand und die Deutschen. Die Wiedervereinigung der Karolingen, Bonn.

Burger W. (1994), Zjednoczenie Niemiec. Społeczno-polityczne i międzynarodowe uwarunkowania, Szczecin.

Czapliński W., Janicki L. (1991), Ważniejsze problemy prawne zjednoczenia Niemiec (z prawnego punktu widzenia), „Przegląd Zachodni”, nr 1.

Cziomer E. (1997), Zarys historii Niemiec powojennych 1945-1995, Warszawa-Kraków.

Czubiński A. (1991a), Przyspieszenie procesu jednoczenia Niemiec, w: Droga Niemców do ponownego zjednoczenia państwa 1949-1990, red. A. Czubiński, Poznań.

Czubiński A. (1991b), Kwestia niemiecka po II wojnie światowej, w: Droga Niemców do ponownego zjednoczenia państwa 1949-1990, red. A. Czubiński, Poznań.

Czubiński A. (1992), Wybrane problemy historii Niemiec XIX i XX wieku, Poznań.

Dokument nr 13, Uktad o ostatecznym uregulowaniu sprawy Niemiec (Układ 2+4 z 12 IX 1990 roku), w: A. Czubiński (1991), Droga Niemców do ponownego zjednoczenia państwa 1949-1990, Poznań. 
Dokument nr 3, Dziesięciopunktowy program kanclerza Helmuta Kohla w sprawie zjednoczenie Niemiec z 28 XI 1989 roku, w: A. Czubiński (1991), Droga Niemców do ponownego zjednoczenia państwa 1949-1990, Poznań.

Dominik E. (2001), Charles de Gaulle: polityk $i$ wizjoner, Warszawa.

Gallet É. (2012), La réception du processus d'unification de l'Allemagne dans les médias britanniques en 1989 et en 1990, „Mémoire(s), identité(s), marginalité(s) dans le monde occidental contemporain: mimmoc", $\mathrm{nr}$ 8, http://mimmoc.revues.org/1068, 12.10.2015.

Genscher H.-D. (1995), Erinnerungen, Berlin.

Giesbert F.-O. (1997), François Mitterrand: die Biographie, Berlin.

Görtemaker M. (1996), Verhandlungen mit den Vier Mächten w: Der Weg zur politischen Einheit. Deutschland seit Mitte der achtziger Jahre, „Informationen zur politischen Bildung”, nr 250.

Grosser A. (1990), Es könnte doch noch schlimmer sein... Eine kritische Betrachtung aus Paris, w: Angst vor Deutschland. Die neue Rolle der Bundesrepublik in Europa und in der Welt, red. U. Wickert, Hamburg.

Guérin-Sendelbach V. (1993), Ein Tandem für Europa? Die deutsch-französische Zusammenarbeit der achtziger Jahre, Bonn.

Guérin-Sendelbach V. (1997), Wiedervereinigung, w: R. Picht, V. Hoffmann-Martinot, R. Lassare, P. Theiner, Fremde Freunde. Deutsche und Franzosen vor dem 21. Jahrhundert, München.

Hacke Ch. (2003), Die Aussenpolitik der Bundesrepublik Deutschland. Von Konrad Adenauer bis Gerhard Schröder, Berlin.

Hailbronner K. (1994), Prawne aspekty zjednoczenia dwóch państw niemieckich, „Przegląd Zachodni", $\mathrm{nr} 4$.

Hatys S. (1990), Stany Zjednoczone wobec jedności Niemiec, „Zeszyty Niemcoznawcze”, Warszawa.

Husson E. (2008), Inne Niemcy, Warszawa.

Janicki L. (1991), Konstytucyjnoprawne podtoże i skutki zjednoczenia, w: Droga Niemców do ponownego zjednoczenia państwa 1949-1990, red. A. Czubiński, Poznań.

Kaiser K. (1991), Deutschlands Vereinigung. Die internationale Aspekte. Mit dem wichtigen Dokumenten, Bonn.

Kiwerska J. (1996), Międzynarodowe uwarunkowania zjednoczenia Niemiec, w: Zjednoczenie Niemiec. Studia politologiczno-ekonomiczno-prawne, red. L. Janicki, B. Koszel, W. Wilczyński, Poznań.

Kiwerska J. (2004), Stosunki francusko-niemieckie, w: Zjednoczone Niemcy. Bilans przemian ekonomicznych, społecznych i politycznych (1990-2002), red. P. Kalka, J. Kiperska, Poznań.

Kohl H. (1999), Pragnałem jedności Niemiec. Kai Diekman, Ralf Georg Reuth relacjonuja rozmowy z Kanclerzem, Warszawa.

Kohl H. (2007), Erinnerungen 1990-1994, München.

Kolboom I. (1991), Deutschlandbilder der Franzosen: Der Tod der Dauerdeutschen, w: G. Trautmann, Die hässlichen Deutschen?, Darmstadt.

Koszel B. (1996), Niemcy w poszukiwaniu nowego miejsca w Europie i świecie, w: Zjednoczenie Niemiec. Studia politologiczno-ekonomiczno-prawne, red. L. Janicki, B. Koszel, W. Wilczyński, Poznań.

Koszel B. (2004), Przyszłość zjednoczonej Europy w koncepcjach Niemiec i Francji, „Przegląd Zachodni", nr 3.

Krasuski J. (1996), Historyczne przesłanki podziału i jedności Niemiec, w: Zjednoczenie Niemiec. Studia politologiczno-ekonomiczno-prawne, red. L. Janicki, B. Koszel, W. Wilczyński, Poznań. 
Kukułka J. (1996), Historia wspótczesna stosunków międzynarodowych 1945-1996, Warszawa.

L'Allemagne fête les 25 ans de sa réunification sur fond de crise des réfugiés, http://www.france24. $\mathrm{com} / \mathrm{fr} / 20151003$-allemagne-fete-25-ans-reunification-rda-merkel-crise-refugies-migrants, 12.10.2015.

La crise des réfugiés pèse sur l'anniversaire de la réunification allemande, http://www.lepoint.fr/monde/la-crise-des-refugies-pese-sur-1-anniversaire-de-la-reunificationallemande-03-10-2015-1970341_24.php, 12.10.2015.

Łastawski K. (2006), Historia integracji europejskiej, Toruń.

Łukaszewski J. (1998), Francja a integracja europejska. Pół wieku ewolucji, w: J. Kranz, J. Reiter, Drogi do Europy, Warszawa.

Maull H. W., Meimeth M., Neßhöver Ch. (1997), Frankreich - Die verhinderte Großmacht?, w: H. W. Maull, M. Meimeth, Ch. Neßhöver, Die verhinderte Großmacht. Frankreich Sicherheitspolitik nach dem Ende des Ost-West - Konflikts, Hemsbach.

Mazur Z. (1990a), Plan Kohla, „Przegląd Zachodni”, nr 3.

Mazur Z. (1990b), Pierwsze reakcje na plan Kohla, ,Przegląd Zachodni”, nr 4.

Mikołajczyk M. (2007), Jean Monnet. Inspirator zjednoczenia Europy, Poznań.

Moisi D. (1991), Auf ein neues „Deutschland über alles”? Sorgen der Französischen Eliten nach dem. 9. November 1989, w: Die häßlichen Deutschen? Deutschland im Spiegel der westlichen und östlichen Nachbarn, red. G. Trautmann, Darmstadt.

Parzymies S. (1990), Francja wobec jedności Niemiec, „Sprawy Międzynarodowe”, nr 7-8.

Parzymies S. (1994), Przyjaźń z rozsadku. Francja i Niemcy w nowej Europie, Warszawa.

Pastusiak L. (1972), Wielkie mocarstwa wobec podziału i zjednoczenia Niemiec, Katowice.

Reunifiaction - Francfort déroule le tapis rouge pour les 25 ans de la réunification allemande, http:// www.lepetitjournal.com/francfort/accueil/actualite/226584-reunification-francfort-deroulele-tapis-rouge-pour-les-25-ans-de-la-reunification-allemande, 12.10.2015.

Rice C., Zelikow P. (1997), Sternstunde der Diplomatie. Die Deutsche Einheit und das Ende der Spaltung Europas, Berlin.

Riklin A. (1964), Das Berlinproblem, Köln.

Romaniuk-Całkowska E. (2004), Rola Francji w integracji politycznej Europy Zachodniej, Toruń.

Schabert T. (2002), Wie Weltgeschichte gemacht wird. Frankreich und die Deutsche Einheit, Stuttgart.

Stadtmüller E. (2002), Niemcy w latach dziewięćdziesiatych, w: Z. Cesarz, E. Stadtmüller, Problemy polityczne wspótczesnego świata, Wrocław.

Stefanowicz J. (1996), Od Kapeta do Mitterranda. Tysiacletni sen o potędze, Warszawa.

Stolarczyk M. (1995), Podział i zjednoczenie Niemiec jako elementy ładów europejskich po drugiej wojnie światowej, Katowice.

Szeptycki A. (2005), Francja czy Europa? Dziedzictwo generała de Gaulle'a w polityce zagranicznej V Republiki, Warszawa.

Teltschick H. (1992), 329 dni. Zjednoczenie Niemiec w zapiskach doradcy kanclerza, Warszawa.

Tomala M. (1990), Polska wobec problem zjednoczenia Niemiec, ,Zeszyty Niemcoznawcze”, Warszawa.

Tomala M. (2000), Zjednoczenie Niemiec. Reakcje Polaków, Warszawa.

Traité de l'Elysée (22 janvier 1963), http://www.france-allemagne.fr/Traite-de-l-Elysee-22janvier-1963,0029.html, 11.10.2016.

Trocini F. (2012), Italian reactions to German reunification - Prejudice and reciprocal misunderstandings, „Mémoire(s), identité(s), marginalité(s) dans le monde occidental contemporain: mimmoc", $\mathrm{nr}$ 8, http://www.openaccessarticles.com/read/380461-1_Italian_reactions_to_ German_reunification_-_Prejudice_and_reciprocal_misunderstandings, 12.10.2015. 
Vertrag über die Beziehungen zwischen der Bundesrepublik Deutschland und den Drei Mächten (Deutschlandvertrag) vom 26. Mai 1952 in der Fassung vom 23. Oktober 1954, http://www. documentarchiv.de/brd/dtlvertrag.html, 11.10.2016.

Watson A. (1998), Niemcy. Kim sq teraz?, Poznań.

Weisenfeld E. (1986), Welches Deutschland soll es sein? Frankreich und das deutsche Einheit seit 1945, München.

Wiaderny-Bidzińska K. (2000), Polityczna integracja Europy Zachodniej, Toruń-Warszawa.

Wickert U. (1990), Weshalb noch Angst vor Deutschland?, w: Angst vor Deutschland. Die neue Rolle der Bundesrepublik in Europa und in der Welt, red. U. Wickert, Hamburg.

Wolff-Powęska A. (2000), Problem niemiecki po zjednoczeniu, „Zeszyty Instytutu Zachodniego”, nr 19.

Yost D. (1990), Frankreich in einem neuen Unfeld, „Europa Archiv”, nr 23.

Zwei Staaten (1989), „Der Spiegel”, nr 52.

\section{Streszczenie}

Artykuł dotyczy polityki Francji wobec zjednoczenia Niemiec. Francja po II wojnie światowej dążyła do utrzymania dobrych relacji z Republiką Federalną Niemiec i Niemiecką Republiką Demokratyczną. Francuzi w sprawie zjednoczenia Niemiec stawiali szereg warunków podkreślając, że zjednoczenie powinno odbyć się w wyniku porozumienia obu państw niemieckich i za zgodą sąsiadów. Francuscy prezydenci, Charles de Gaulle, Georges Pompidou, Valery Giscard d'Estaing i François Mitterrand, starali się prowadzić politykę tenir le range w kontaktach z Niemcami.

Słowa kluczowe: Francja, zjednoczenie Niemiec

\section{France and the Reunification of Germany after second World War}

\section{Summary}

In the article I have analyzed France's politics to the problem of Germany's reunification. After world war II France wanted to keep a good relationship with the Federal Republic of Germany and the German Democratic Republic. French politicians presented a series of prerequisites of Germany's reunification emphasizing, that the reunification should result from an agreement between both German countries and with approval of their neighboring countries. The French presidents: Charles de Gaulle, Georges Pompidou, Valery Giscard d'Estaing and François Mitterrand wanted to implement the policy of tenir le range in the relationship with Germany.

Key words: France, Reunification of Germany 